haste — lists ending lamely with an "etc." or "and so forth". Dating the Indian Kharosthi script to "the first few centuries BC" is careless writing when what he means is the last few. It is not always clear when Fischer is writing on his own authority and when he is following a secondary source. He can even send us to a general book on the alphabet written 60 years ago as his support for saying that the Arabic and Hebrew scripts are both historically tied to a particular religion. This is odd rather than sinful. But to tell us something that is not generally accepted - such as that Cyprus is the place of origin of the Greek alphabet - without providing evidence, is less excusable. It is worse still when Fischer states that the undeciphered pre-Mycenaean Cretan scripts (including the notorious Phaistos Disk) have been deciphered as Greek. The 'decipherment', however, is Fischer's own and hardly anyone else accepts it. The claim is one that should not have been made in a general book where it is likely to mislead non-experts.

But unwavering orthodoxy would be dull. What is wonderful is to see a subject that embraces so much of human civilization handled with the wide knowledge and breadth of vision that it deserves.

Maurice Pope is at 26 Lathbury Road, Oxford OX2 7AU, UK.

New in paperback by the same author A History of Language

by Steven Roger Fischer

Reaktion Books, £9.95, \$17.95

\section{Golem schmolem}

\section{Kiln People \\ by David Brin \\ Tor: 2002. 336 pp. $\$ 25.95$ \\ Henry Gee}

According to Jewish folklore, a sixteenth-century rabbi of Bohemia called Yehuda Loew devised an antidote to anti-Semitic attacks: a vengeful automaton made of clay, animated with a scrap of parchment bearing one of the ineffable names of God. This automaton was called the golem. The story of Rabbi Loew, however, is not unique. The golem is mentioned in the Talmud, that sprawling compendium of ancient Jewish scholarship — in which, among other matters, scholars debated whether a golem was human enough to make a congregation quorate.

The Talmud, then, was arguably the first forum to debate the legal and social status of artificial people. The Western canon caught up in 1818, with the publication of Mary Shelley's novel Frankenstein. Like the passages in the Talmud that talk of the golem, Frankenstein is an extended debate on whether the feelings and motivations of artificial people can be judged as equivalent to those of humans.

The modern concept of automata, like the legend of Rabbi Loew, was a thoroughly

\section{On the jungle beat}

A day gecko (Phelsuma madagascariensis), below, and a cercopithecus (Cercopythecus mona). From Secret Jungle by Nicole Viloteau

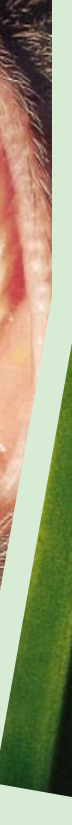

(Flammarion, \$40).

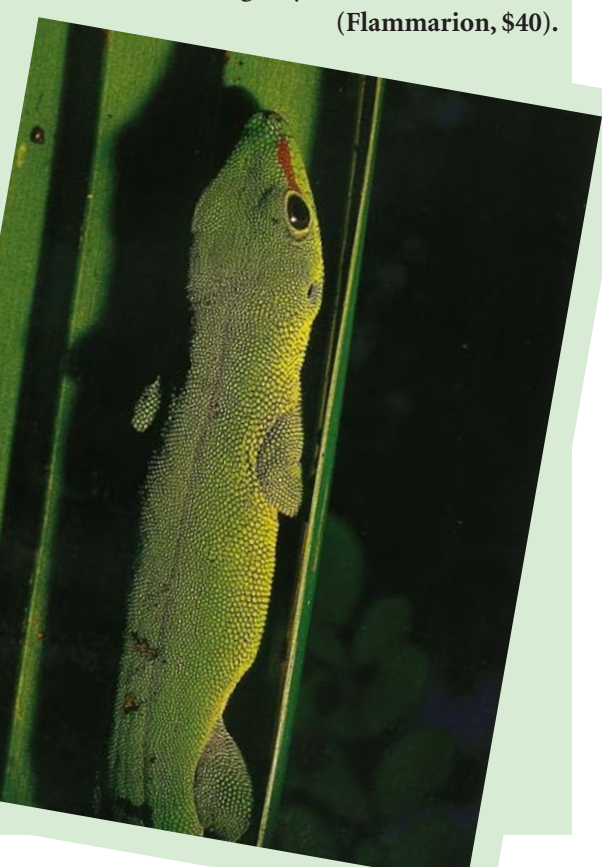

Bohemian rhapsody. In 1921, the Czech dramatist Karel Capek staged his play RUR ('Rossum's Universal Robots'). In Czech, the word robota means work, but with overtones of the obligations of serfdom. Capek was the first to use 'robot' to mean an automaton in the guise of a human being, created to do the jobs that real-life humans found dull. Since then, robots have been a staple of science fiction, from Isaac Asimov's robot stories of the 1950s to the droids of Star Wars fame and the replicants of Blade Runner, Ridley Scott's film based on Philip K. Dick's story Do Androids Dream of Electric Sheep?

David Brin's latest novel brings the golem up to date. Kiln People is a detective story set in a world in which making golems is as easy as making toast. Universal Kilns, a vast conglomerate, supplies citizens of the future with inert clay mannequins which, when animated with the imprint of the customer's 'soul wave' and baked in a kiln, produce replicas of the user that can be despatched on all sorts of errands, from doing the shopping to industrial espionage and even armed combat. After a light breakfast, you can imprint a few golems, send them off to work, and spend the rest of the day playing golf. At the end of the day, your golems (Brin calls them 'dittos') will return home, download their experiences into your brain, and dissolve into a recyclable, clayey sludge.

Kiln People centres around the exploits of gumshoe Albert Morris, who specializes in tracking down counterfeiters who churn out cheap knock-offs of 'pleasure' dittos imprinted with the soul waves of celebrity courtesans. Morris is a twenty-secondcentury Sam Spade, and at one level, Kiln People is a stylish noir thriller that follows all the conventions of the genre. Morris is the brilliant-yet-flawed loner amid a cast of stereotypes: there are wise-cracking villains, gun-toting mobsters, enigmatic and beautiful ladies with dark secrets and super-wealthy sugar-daddies.

So far, so LA Confidential. The twist is 'dittotech', which allows Morris - and everyone else - to be in several places at once, packing more incident into a day than most people could handle in a month. The plot is serpentine, to say the least, and the reader has to be able to follow several parallel plot strands as various copies of Morris - and Morris himself - investigate a seemingly endless brew of intrigue, double-cross and treble-bluff. At times the story threatens to collapse into chaos, like a golem at eventidebut it is saved by a use of language as artful as that of Chandler or Hammett. ("Me, I was one of a vanishing breed - the employed," says Morris. "Why stay in school when you have a marketable skill? You never know when it'll become obsolete.") Everything pulls together at the last minute in a suitably apocalyptic ending involving the archetypal mad scientist — but, hey! I'm telling you the plot. 
The noir stylings don't disguise Kiln People's homage to the postwar 'golden age' of American SF. Many famous SF stories imagine otherwise familiar surroundings coming to terms with a single, worldchanging innovation. In Kiln People it's dittotech, in the same way that in Alfred Bester's The Stars My Destination (Millennium Books, 1999) it is the ability to flip yourself from place to place at will. Bester's anti-hero, Gully Foyle, happens to be a master of quantum jumping, in the same way that Albert Morris has a soul-wave ideally suited to turning out reliable dittos a kink on which the book turns.

Why is the golem - and the robot, its latter-day incarnation - such an enduring device in literature and legend? The easy answer is that it is a metaphor for the human condition: the golem stands to mankind as mankind stands to God. The first golem was Adam, a man made from clay and animated with the Divine spark: the Hebrew words for 'man' and 'clay' share the same root. It is a mark of mankind's very humanity that the golem, although realistic, is never quite as good as the real thing, for the preserve of creation rests with God himself.

Another recent and remarkable manifestation is a short story by self-confessed 'occasional' SF author Ted Chiang. His "Seventy-Two Letters" (in Year's Best SF6, edited by David G. Hartwell; Eos, 2000) takes place in an alternative Victorian reality in which many alchemical conceits are scientific reality, and factories generate golems for specific purposes, dictated by the Hebrew acrostics inserted into their mouths matrices of 72 Hebrew letters, arranged by skilled 'software' programmers. It is no coincidence that the more mystical byways of Jewish lore contain several formulae of God's name, the most complicated of which is based on a 72-letter acrostic. And so the story of the golem comes full circle.

Henry Gee is a senior editor at Nature.

\section{A celebration of science}

The Science Book

edited by Peter Tallack

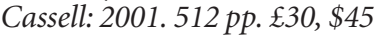

\section{Fran Balkwill}

"The first truly accessible, lavishly illustrated story of science," heralds the cover of this weighty tome. Beginning at 35,000 BC with the origins of counting, The Science Book spans the millennia with achievements and advances in astronomy, biology, chemistry, cosmology, evolution, geology, mathematics, medicine, physics, etc., etc. A total of 250 scientific milestones are each awarded a double-page spread: the left-hand page describes, in about 500 words, a particular discovery and the scientist(s) responsible;

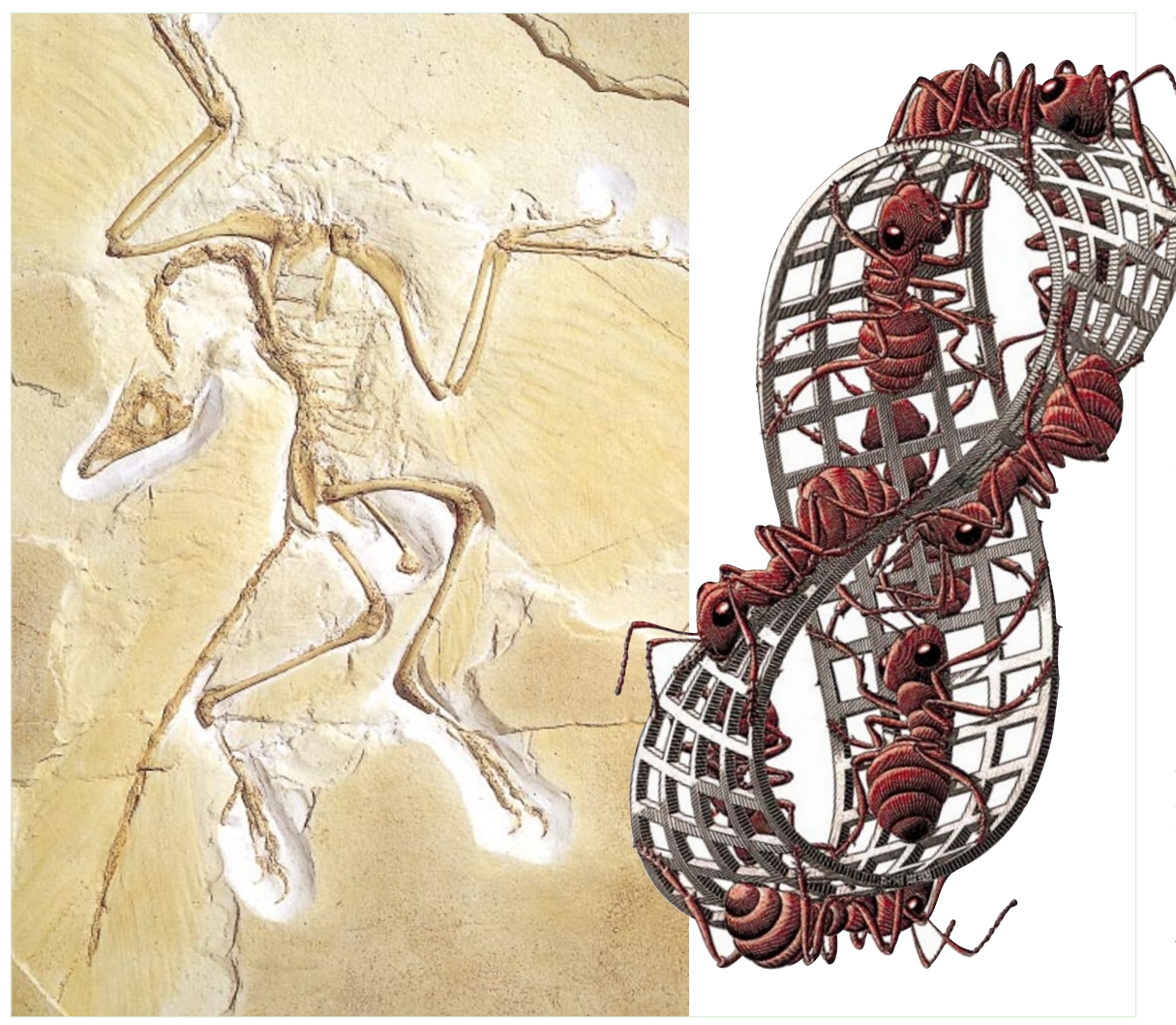

The flying and the crawling: Archaeopteryx, and red ants demonstrating non-euclidean geometry. the right comprises a well-selected and often arresting image. There is an enthusiastic preface from Susan Greenfield, a foreword by Simon Singh, and the entries are interspersed with selected writings by an impressive line-up of luminaries, including Peter Atkins, W. Daniel Hillis, Richard Dawkins, Jared Diamond, Richard Leakey, Steven Pinker, Martin Rees and Ian Stewart.

And, yes, the book is accessible. Many prizewinning popular-science books are too difficult for the general reader. But, with less than 500 jargon-free words for each entry, the text of The Science Book brings out the salient points in a way that should be clear to most people. The spacious text layout and generous type size certainly draw the reader to each page, and the attention span required for an individual entry is highly suitable for the Sesame Street generations.

Science stories are exciting, and science fact is usually stranger and more amazing than science fiction. Yet I found the quality of the individual entries variable. Some were rather pedestrian and, in one case where I know the field, there were worrying inaccuracies. Also, there were omissions. But, as Peter Tallack admits in the introduction, the selection is inevitably subjective, and even science can be a matter of taste. In the field of biomedicine, additional entries on anaesthesia, stem cells, interferon and especially in view of the recent Nobel awards - the cell cycle would get my vote.

The chronological structure of the book works well, giving an insight into trends and influences across the centuries. This is helped by extensive cross-referencing. But there was no attempt to lead the reader further into the world of science. The index for this celebration of human achievement comprises just one doublepage spread. A glossary, bibliography or list of useful Internet sites would all have been helpful. Although this book might well be inspirational for a child or teenager, it may not provide enough detail for that late-night, last-minute, science homework project.

The Science Book is, as it claims, lavishly illustrated, and in most cases the illustrations, which completely cover the righthand page of each entry, are appropriate, stunning and original. Much can be gained by simply browsing through the pictures, as with other 'coffee-table' books. As I don't have a coffee table, The Science Book has been occupying sofa space for the past two weeks. There have been mixed reactions from non-scientist visitors (age range 17-60). Some were encouraging - 'original', 'innovative', 'helps me understand how things were discovered', 'great images', 'useful'. But other comments were not so flattering — 'Reader's Digest book of science', 'a missed opportunity', 